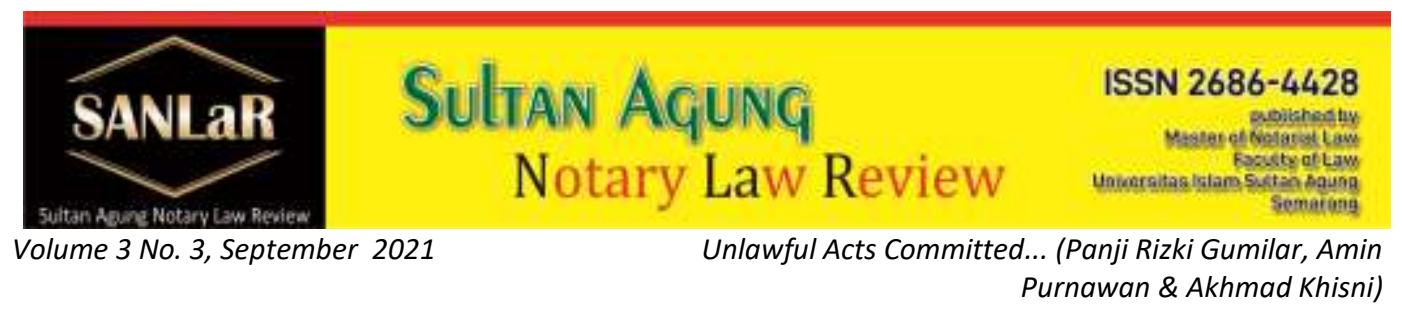

\title{
Unlawful Acts Committed by a Notary in Form of Not Completing the Mortgage Process
}

\author{
Panji Rizki Gumilar*), Amin Purnawan ${ }^{* *}$ and Akhmad Khisni***) \\ $\left.{ }^{*}\right)$ Faculty of Law, Universitas Islam Sultan Agung (UNISSULA) Semarang, E-mail: \\ panjirg2021@gmail.com
}

${ }^{* *}$ Faculty of Law, Universitas Islam Sultan Agung (UNISSULA) Semarang, E-mail:
amin.p@unissula.ac.id

$\left.{ }^{* * *}\right)$ Faculty of Law, Universitas Islam Sultan Agung (UNISSULA) Semarang, E-mail: khisni@unissula.ac.id

\begin{abstract}
Public trust in the notary is the public's trust in the authentic deed he made, which is why the position of a notary is often also called the position of trust. Notaries as public officials are required to be responsible for the authentic deeds that they have made. A notary as a public official is required to be responsible for the authentic deed he has made. This is contained in UUJN no. 30 of 2004 concerning the position of a notary. The objectives of this study are as follows, one to identify and analyze the roles and responsibilities of a notary in a credit binding agreement, second to find out and analyze legal sanctions for a notary who does not complete the mortgage process and the study certificate process at the Central Artha People's Credit Bank, Brebes branch. . The approach method in this research is descriptive, which is carried out with a normative juridical approach. The type of research data used is secondary data consisting of primary legal materials and secondary legal materials. Analysis Data obtained from research results in the form of library research data (secondary) are analyzed qualitatively, the results of this study Notaries are public officials authorized to make authentic deeds insofar as the making of certain authentic deeds is not reserved for other public officials. Making authentic deeds is required by laws and regulations in order to create certainty, order, and legal protection. In addition to an authentic deed made by or before a Notary, not only because it is required by laws and regulations, but also because it is desired by interested parties to ensure the rights and obligations of the parties for the sake of certainty, order, and legal protection for interested parties at the same time for society as a whole.
\end{abstract}

Keywords: Responsibility; Notary; Mortgage; Rights; Sanctions. 


\section{Introduction}

Economic development, as part of national development, is one of the efforts to create a just and prosperous people. In order to maintain the sustainability of the development, the actors including both the government and the community as individuals and legal entities, really need large amounts of funds, this results in increased development activities, also increasing the need for the availability of funds, most of which are obtained through credit activities.

Given the importance of these credit funds in the development process, credit providers and recipients as well as other related parties should receive protection through a strong guarantee rights institution that can provide legal certainty for all interested parties. In Article 51 of Act No. 5 of 1960 concerning the Basic Agrarian Law (UUPA) has provided a strong guarantee rights institution, namely Mortgage Rights that can be imposed on land rights as a substitute for hypotheek and creditverband. For more than 30 (thirty) years since the enactment of the LoGA, the Mortgage Rights institution has not been able to function properly, because there is no full regulation of the Act. During this period, the Transitional Provisions, namely Article 57 of the LoGA, still apply the provisions of the hypotheek as regulated in book II of the Civil Code, and the provisions on creditverband in Stb. 1908 No. 542 which has been amended by Stb. 1937 No.190.

A comprehensive understanding of the problem of installing mortgages is very necessary for follow-up. We will try to take inventory, identify and discuss the constellation of problems in the field of mortgage installation which is empirically very complex. Seeing the many problems that occur in banking regarding the existence of a notary's responsibility in credit and certification rights which often occur in banking, this journal research will discuss it with the main problem, namely how the role and responsibilities of a notary in credit binding agreements and what are the legal sanctions for a notary who does not complete the mortgage and certificate process ${ }^{1}$.

\section{Research Methods}

The approach method in this research is descriptive, which is carried out with a normative juridical approach. Descriptive research is intended to provide as detailed data as possible about humans, conditions and other symptoms. The

\footnotetext{
${ }^{1}$ Ong Argo Victoria, Ade Riusma Ariyana, Devina Arifani. (2020). Code of Ethics and Position of Notary in Indonesia. Sultan Agung Notary Law Review 2 (4), 397-407, http://lppmunissula.com/iurnal.unissula.ac.id/index.php/SANLaR/article/view/13536 see Yaya Kareng, Ong Argo Victoria, R. Juli Moertiyono. (2019). How Notary's Service in Thailand. Sultan Agung Notary Law Review, 1 (1), 46-56, http://jurnal.unissula.ac.id/index.php/SANLaR/article/view/4435
} 
type of research data used is secondary data consisting of primary legal materials and secondary legal materials, namely research materials taken from books, papers, results of previous research, norms and legislation by conducting interview sessions to achieve good results and then data analysis obtained from the research results in the form of data from library research (secondary) analyzed qualitatively.

Based on the problems that have been formulated above, the purpose of this research is is to identify and analyze the roles and responsibilities of a notary in the credit binding agreement and to identify and analyze legal sanctions for a notary who does not complete the mortgage and certificate process.

\section{Result and Discussion}

\subsection{A Public Notary}

A notary is a public official who is authorized to make an authentic deed as long as the making of a certain authentic deed is not reserved for other public officials. Making authentic deeds is required by laws and regulations in order to create certainty, order, and legal protection.

There are 2 forms of deed or credit agreement used in a credit agreement:

\section{Notary credit deed/agreement (authentic)}

Notary or authentic credit deed or agreement means that the deed or agreement must be made before a public official or notary.

\section{Deed/Credit Agreement Under Hand}

An underhand credit agreement is an agreement made and signed between the debtor and the creditor without being before a notary even sometimes without witnesses who also signed, even though the witness is one of the tools for proving this underhand credit agreement can be charged into two, among others $^{2}$ :

a. Legalized underhand deed, that is, the signing of the deed must be in front of an authorized official, thus both the date and the signer are guaranteed certainty, besides that the contents of the deed are also read out by the public official to the appearers.

\footnotetext{
2 Deen, Thaufiq., Ong Argo Victoria \& Sumain. (2018). Public Notary Services In Malaysia. JURNAL AKTA: Vol. 5, No. 4, 1017-1026. Retrieved from http://jurnal.unissula.ac.id/index.php/akta/article/view/4135
} 
b. The registered deed (warmeking) is only registered by the authorized official, so for that it is only guaranteed that the date when the deed is registered, while the contents and signing cannot be accounted for, because it is only made by the parties themselves. , then the deed will only have the strength of material evidence, if its formal strength has been proven.

The difference between an authentic deed and a deed made under the hand:

1. Authentic deeds have a definite date, while regarding the date of the deed made under the hand, this is not always the case

2. grosse The authentic deed in some cases has executive power such as a judge's decision, while the deed made under the hand never has executive power.

3. the possibility of the loss of the deed made under the hand is greater than the authentic deed

The power of proof of an authentic deed made by a Notary has 3 powers of proof:

1. power of outward proof (uitwendige bewijsracht)

2. power of formal proof (formele bewijskracht)

3. power of material proof (materiele bewijskracht)

In carrying out his role as a credit agreement deed official, a Notary has the following duties and authorities:

1. The duties of a Notary in a credit agreement as a Bank partner are:

a. Assigned to make a deed of credit agreement requested by the bank.

b. For the credit documents made, the Notary is responsible for:

1) The truth, accuracy and completeness of the documents presented

2) Leaking bank secrets,

3) Problems with the documents he created

4) Notaries are in charge and responsible for providing guidelines, instructions, guidance to banks related to credit documents

5) A notary is in charge of making a final credit document based on a concept that has been approved by the bank.

6) The notary is in charge of confirming the data to the bank if there are things that are not or less clear and submitting the draft document to the bank.

7) Duty to keep the name of the debtor and the amount of credit requested.

8) Assigned to enter into the register book in order to be registered with the District Court.

Authority of Notary in credit agreement as Bank partner

1. The authority to make a deed of credit agreement based on clear data and information 
2. The authority to legalize or refuse to make a credit agreement deed, for reasons that can be accepted by law or for reasons that the credit agreement is detrimental to both the Creditor and the Debtor.

3. The authority to ratify if the requirements for completeness of the file have not been fulfilled by the Debtor or Creditor.

4. The authority to request compensation for services in the form of money from the bank for the preparation, management and completion of documents that have been carried out, the amount of which is determined on the basis of an agreement between the customer and the Partner known by the bank, taking into account the level of difficulty of the work, the prevalence and applicable provisions.

5. The authority to contact banks to offer services according to their respective potentials.

\subsection{Legal Sanctions for Notaries Who Don't Complete the Mortgage Process and Certificate Process}

Notaries in carrying out their positions must be based on accuracy, precision, and accuracy. Three elements of personal traits that must receive special attention that shape character in carrying out their positions are: ${ }^{3}$

1. Be honest with yourself

2. Good and true

3. Professional

Forms of Responsibilities of Notaries Who Don't Complete the Mortgage Process and Certificate Process.

1. Forms of Responsibilities of a Notary in terms of Administrative Law

Administrative legal sanctions against a notary because of his mistake in making an authentic deed according to Article 85 of the UUJN concerning the provisions referred to in Article 7, Article 15 paragraphs (1, 2 and 3), Article 16 paragraph (1) letter (a), (b), (c), (d), (e), (f), (g), (h), (i), (j), (k), Article 17, Article 20, Article 27, Article 32, Article 37, Article 54, Article 58 and or Article 63, may be subject to sanctions in the form of:

a. verbal reprimand;

b. written warning;

c. Temporary suspension;

d. Dismissal with honor;

${ }^{3}$ A.A.Andi Prajitno, 2010, Apa Dan Siapa Notaris di Indonesia, Putra Media Nusantara, Jakarta 62 
e. Disrespectful dismissal;

2. Forms of Responsibilities of a Notary in terms of Civil Law

By making compensation on the basis of unlawful acts in civil law, it is regulated in Article 1365 of the Civil Code which stipulates "Every unlawful act that brings harm to another person, requires the person who because it is legal to issue the loss, replaces the loss.

3. Forms of Notary Responsibilities in terms of Criminal Law ${ }^{4}$

If there is a notary deed that is disputed by the parties or other parties, the notary is often withdrawn as a party participating in committing or helping to commit a crime. To request a notary statement on a report of a certain party according to Article 66 of Act No. 2 of 2014 concerning the Position of a Notary, if a notary is summoned by the police, prosecutors or judges, the agency wishing to summon must seek approval from the Notary Honorary Council.

\section{Closing}

A notary is a public official who is authorized to make an authentic deed as long as the making of a certain authentic deed is not reserved for other public officials. Making authentic deeds is required by laws and regulations in order to create certainty, order, and legal protection. In addition to an authentic deed made by or before a Notary, not only because it is required by laws and regulations, but also because it is desired by interested parties to ensure the rights and obligations of the parties for the sake of certainty, order, and legal protection for interested parties at the same time for society as a whole. A notary is a human being who does not escape from mistakes in making the deed, for that if it occurs either by intention or negligence, the notary makes a mistake, can be held accountable both in terms of criminal law, civil, and administrative.

\section{References}

Journals:

[1] A Chuasanga, Ong Argo Victoria. (2019). Legal Principles Under Criminal Law in Indonesia and Thailand, Jurnal Daulat Hukum, Vol 2, No 1 (2019) http://jurnal.unissula.ac.id/index.php/RH/article/view/4218

[2] Deen, Thaufiq., Ong Argo Victoria \& Sumain. (2018). Public Notary Services In Malaysia. JURNAL AKTA: Vol. 5, No. 4, 1017-1026. Retrieved from http://jurnal.unissula.ac.id/index.php/akta/article/view/4135

\footnotetext{
${ }^{4}$ A Chuasanga, Ong Argo Victoria. (2019). Legal Principles Under Criminal Law in Indonesia and Thailand, Jurnal Daulat Hukum, Vol 2, No 1 (2019) http://jurnal.unissula.ac.id/index.php/RH/article/view/4218
} 
[3] Habib Adjie, Undang-Undang Jabatan Notaris sebagai Unifikasi Hukum Pengaturan Notaris, Majalah Renvoi No. 28 Ke III, September 2005.

[4] Henricus Subekti, Tugas Notaris (perlu) diawasi, Majalah Renvoi, No. 26, Third Print. , April 2006.

[5] Herlien Budiono, Artikel "Pengikatan Jual Beli dan Kuasa Mutlak" Majalah Renvoi, Edition I, No. 10, March 2004.

[6] Herlien Budiono, Asosiasi Notaris, Suatu Jalan Keluar?, Media Notariat, No. 2 I, 1999.

[7] Moh. Mahfud MD, Penegakan Hukum DanTata Kelola Pemerintahan Yang Baik, Bahan pada Acara Seminar Nasional "Saatnya Hati Nurani Bicara” Mahkamah Konstitusi Jakarta, 8 January 2009.

[8] Ong Argo Victoria, Ade Riusma Ariyana, Devina Arifani. (2020). Code of Ethics and Position of Notary in Indonesia. Sultan Agung Notary Law $\begin{array}{lllll}\text { Review } & 2 & (4), & \text { 397-407, }\end{array}$ unissula.com/jurnal.unissula.ac.id/index.php/SANLaR/article/view/13536

[9] Roenastiti Prayitno, Notaris Ideal dan Profesional, Media Notariat, Edition April-June 2001

[10] Yaya Kareng, Ong Argo Victoria, R. Juli Moertiyono. (2019). How Notary's Service in Thailand. Sultan Agung Notary Law Review, 1 (1), 4656, http://jurnal.unissula.ac.id/index.php/SANLaR/article/view/4435 